\title{
Liver Necrosis and Lipid Peroxidation in the Rat as the Result of Paraquat and Diquat Administration
}

\author{
EFFECT OF SELENIUM DEFICIENCY
}

\author{
RAymond F. Burk, Richard A. LaWrence, and James M. LANe, Liver and \\ Nutrition Unit, Department of Medicine and Department of Biochemistry, \\ Louisiana State University School of Medicine, Shreveport, Louisiana 71130
}

\begin{abstract}
A B S T R A C T Paraquat and diquat facilitate formation of superoxide anion in biological systems, and lipid peroxidation has been postulated to be their mechanism of toxicity. Paraquat has been shown to be more toxic to selenium-deficient mice than to controls, presumably as the result of decreased activity of the selenoenzyme glutathione peroxidase. The present study was designed to measure lipid peroxidation and to assess toxicity in control and selenium-deficient rats given paraquat and diquat. Lipid peroxidation was measured by determining ethane production rates of intact animals; toxicity was assessed by survival and by histological and serum enzyme evidence of liver and kidney necrosis. Paraquat and diquat were both much more toxic to selenium-deficient rats than to control rats. Diquat $(19.5 \mu \mathrm{mol} / \mathrm{kg})$ caused rapid and massive liver and kidney necrosis and very high ethane production rates in selenium-deficient rats. The effect of paraquat $(78 \mu \mathrm{mol} / \mathrm{kg}$ ) was similar to that of diquat but was not as severe. Acutely lethal doses of paraquat $(390 \mu \mathrm{mol} / \mathrm{kg})$ and diquat $(230 \mu \mathrm{mol} / \mathrm{kg})$ in control rats caused very little ethane production and no evidence of liver necrosis. These findings suggest that paraquat and diquat exert their acute toxicity largely through lipid peroxidation in selenium-deficient rats. Selenium deficiency had no effect on superoxide dismutase activity in erythrocytes or in $105,000 \mathrm{~g}$ supernate of liver or kidney. Glutathione peroxidase, which represents the only well-characterized biochemical function of selenium in animals, was dissociated from the protective effect of selenium against diquat-induced lipid peroxi-
\end{abstract}

This work was published in part in abstract form in 1979 . Gastroenterology. 76: 1109.

As of 1 April 1980, Dr. Burk's address will be Department of Medicine, University of Texas Health Science Center, San Antonio, Tex.

Received for publication 1 October 1979 and in revised form 26 November 1979. dation and toxicity by a time-course study in which selenium-deficient rats were injected with $50 \mu \mathrm{g}$ of selenium and later given diquat $(19.5 \mu \mathrm{mol} / \mathrm{kg})$. Within $10 \mathrm{~h}$, the selenium injection provided significant protection against diquat-induced lipid peroxidation and mortality even though this treatment resulted in no rise in glutathione peroxidase activity of liver, kidney, lung, or plasma at $10 \mathrm{~h}$. This suggests that a seleniumdependent factor in addition to glutathione peroxidase exists that protects against lipid peroxidation.

\section{INTRODUCTION}

Paraquat (1,1'-dimethyl-4,4'-bipyridylium-dichloride) and diquat (1,1'-ethylene-2,2'-bipyridylium-dichloride) are bipyridylium compounds that are extremely toxic to plants and animals. They are widely used as herbicides, and accidental as well as intentional paraquat poisonings of human beings have been reported (1). Paraquat causes lung injury that is worsened by increasing the $\mathrm{O}_{2}$ concentration in inspired air (2). Diquat causes death in animals but little pathology is noted (3).

These compounds accept electrons from cellular electron transfer systems and donate them to $\mathrm{O}_{2}$, forming the superoxide anion $\mathrm{O}_{2}^{\bar{*}}(4)$. This process is thought to underlie their toxicity to plants and animals. Bus et al. (5) have postulated that $\mathrm{O}_{2}^{-}$-mediated lipid peroxidation is responsible for the lung injury due to paraquat. They envision that paraquat would increase the formation of $\mathrm{O}_{2}^{\bar{z}}$ beyond the capacity of lung superoxide dismutase to convert it to $\mathrm{H}_{2} \mathrm{O}_{2}$, and that spontaneous dismutation would yield singlet oxygen, ${ }^{1} \mathrm{O}_{2}$, as one product that in turn would attack polyunsaturated fatty acids to yield fatty acid hydroperoxides. Further breakdown of the fatty acid hydroperoxides would cause membrane injury and lead to cell death. Additional evidence that paraquat toxicity is 
mediated by lipid peroxidation is the fact that selenium deficiency potentiates paraquat lung injury in rats (6) and even allows liver injury in mice (7). Liver injury does not occur in control mice given paraquat.

Selenium is an essential constituent of the enzyme glutathione peroxidase (EC 1.11.1.9) and the activity of this enzyme in lung and liver is very low in seleniumdeficient animals. Because glutathione peroxidase is thought to remove lipid hydroperoxides in vivo, diminution of its activity would be expected to lead to an increase in lipid peroxidation. The lipid peroxidation hypothesis of paraquat toxicity has been challenged, however, by Shu et al. (8), who found no products of lipid peroxidation in the lungs of paraquat-treated mice, and by Steffen and Netter (9), who failed to detect lipid peroxidation in in vitro studies using liver microsomes and paraquat.

Until recently, the detection of lipid peroxidation in vivo has been very difficult. It has depended on postmortem demonstration in tissues of lipid peroxidation products such as conjugated dienes and malonaldehyde. The presence of these substances is of uncertain significance because they are normally metabolized in vivo and their formation during tissue preparation is difficult to exclude. In 1974 Riely et al. (10) proposed the use of breath ethane measurements as an index of in vivo lipid peroxidation. They reported that mice given carbon tetrachloride exhaled large amounts of ethane, presumably as the result of peroxidative decomposition of polyunsaturated fatty acids. Further work by other groups has confirmed the value of breath ethane measurements as an index of in vivo lipid peroxidation $(11-13)$. In this study we have employed ethane production-rate measurements to assess the role of lipid peroxidation in the toxicity of paraquat and diquat to control and selenium-deficient rats.

\section{METHODS}

Animals. Male Holtzman rats (Holtzman Co., Madison, Wis.) were fed a Torula yeast-based diet (14) and provided with tap water ad lib. from weaning until they were studied 3-5 mo later. The control diet contained $0.5 \mathrm{mg}$ of selenium $/ \mathrm{kg}$ as $\mathrm{Na}_{2} \mathrm{SeO}_{3}$ and $100 \mathrm{IU}$ of DL-alpha-tocopheryl acetate $/ \mathrm{kg}$. The vitamin Edeficient diet was the same as the control except that no DLalpha-tocopheryl acetate was added, and corn oil was replaced by vitamin E-stripped corn oil. The selenium-deficient diet had the same composition as the control diet except that no selenium was added. For the experiments in Tables I and II, some of the rats were fed a diet in which the corn oil content had been reduced from 6.7 to $4 \%$ and $4 \%$ cod liver oil had been added.

Rats were killed by cervical dislocation. They were immediately bled into a centrifuge tube, and serum was separated by centrifugation. Blood was taken from moribund rats by cardiac puncture and serum was separated. In the selenium repletion experiment, the rats were anesthetized with diethyl ether and blood was taken from the aorta. Disodium EDTA (1 $\mathrm{mg} / \mathrm{ml}$ ) was added to prevent clotting and plasma was separated by centrifugation. The liver, lungs, and kidneys were perfused with cold $1.15 \% \mathrm{KCl}$, excised, blotted, and weighed. $10 \%$ homogenates were made in $0.25 \mathrm{M}$ sucrose and sonicated. Paraquat and diquat were administered intraperitoneally and dissolved in $1 \mathrm{ml}$ or less of $0.14 \mathrm{M} \mathrm{NaCl}$. Selenium as $\mathrm{Na}_{2} \mathrm{SeO}_{3}$ was injected intraperitoneally and dissolved in $1 \mathrm{ml} \mathrm{of} 0.14 \mathrm{M}$ $\mathrm{NaCl}$.

Assays. Serum glucose was measured by the glucose oxidase-horseradish peroxidase kit method from Boehringer Mannheim Biochemicals, Indianapolis, Ind. Serum glutamicpyruvic transaminase (SGPT) ${ }^{1}$ was measured on the day of sample collection by a kit method (Single Vial, Boehringer

\footnotetext{
${ }^{1}$ Abbreviation used in this paper: SGPT, serum glutamicpyruvic transaminase.
}

TABLE I

Ethane Production and Organ Necrosis as the Result of Paraquat and Diquat*

\begin{tabular}{|c|c|c|c|c|c|c|}
\hline \multirow[b]{2}{*}{ Diet group } & \multirow[b]{2}{*}{ Agent } & \multirow[b]{2}{*}{ Dose } & \multirow{2}{*}{$\begin{array}{c}\text { Ethane } \\
\text { produced/100 } \mathrm{g} / \mathrm{ht}\end{array}$} & \multirow[b]{2}{*}{ SGPT } & \multicolumn{2}{|c|}{ Histological necrosis } \\
\hline & & & & & Liver & Kidney \\
\hline & & $\mu \mathrm{mol} / \mathrm{kg}$ & pmol & $m U / m l$ & & \\
\hline \multirow[t]{2}{*}{ Control } & Paraquat & 78 & $95 \pm 25$ & $17 \pm 6^{\prime \prime}$ & $0.4 \pm 0.5$ & 0 \\
\hline & Diquat & 78 & $232 \pm 42$ & $19 \pm 4^{\prime \prime}$ & $0.1 \pm 0.3$ & 0 \\
\hline \multirow{2}{*}{$\begin{array}{r}\text { Vitamin E- } \\
\text { deficient }\end{array}$} & Paraquat & 78 & $407 \pm 96$ & $38 \pm 20^{\prime \prime}$ & $0.1 \pm 0.3$ & 0 \\
\hline & Diquat & 78 & $695 \pm 84$ & $-\S$ & $0.6 \pm 0.6$ & $0.8 \pm 1.5$ \\
\hline \multirow{2}{*}{$\begin{array}{l}\text { Selenium- } \\
\text { deficient }\end{array}$} & Paraquat & 19.5 & $49 \pm 9$ & $31 \pm 7^{\prime \prime}$ & $0.1 \pm 0.3$ & 0 \\
\hline & Diquat & 19.5 & $6,540 \pm 1,200$ & $4,280 \pm 4,050$ & $2.3 \pm 1.3$ & $2.5 \pm 0.6$ \\
\hline
\end{tabular}

* Rats were fed the diet containing cod liver oil and had been fasted $16 \mathrm{~h}$. All values are means $\pm \mathrm{SD}$ for four rats. \$ Ethane production was measured for $6 \mathrm{~h}$ except for the selenium-deficient rats receiving diquat. They died in the chambers at an average of $110 \mathrm{~min}$ after injection. Basal ethane production rates have been subtracted. They were $(n=5)$ : control $36 \pm 11$, vitamin E deficient $184 \pm 57$, selenium deficient $47 \pm 9$.

$\$$ All rats died $10-24 \mathrm{~h}$ after injection and no serum was obtained.

"All rats survived $24 \mathrm{~h}$. 
TABLE II

Effect of Dietary Fat Source on Ethane Production and Survival Time after Diquat Administration to Selenium-deficient Rats*

\begin{tabular}{|c|c|c|c|c|c|c|}
\hline \multirow[b]{2}{*}{$\begin{array}{l}\text { Dietary } \\
\text { fat source }\end{array}$} & \multirow{2}{*}{$\begin{array}{c}\text { Ethane } \\
\text { produced/100 } \mathrm{g} / \mathrm{h} \ddagger\end{array}$} & \multirow[b]{2}{*}{ SGPT } & \multirow{2}{*}{$\begin{array}{l}\text { Serum } \\
\text { glucose at death }\end{array}$} & \multirow{2}{*}{$\begin{array}{c}\text { Survival } \\
\text { time }\end{array}$} & \multicolumn{2}{|c|}{ Histological necrosis } \\
\hline & & & & & Liver & Kidney \\
\hline & pmol & $m U / m l$ & $m g / d l$ & $\min$ & & \\
\hline Corn oil & $2,810 \pm 101 \S$ & $4,120 \pm 529$ & $328 \pm 102$ & $123 \pm 21 \S$ & $3.0 \pm 0$ & $3.8 \pm 0.5$ \\
\hline Cod liver oil & $9,000 \pm 2,830 \S$ & $3,760 \pm 2,510$ & $225 \pm 140$ & $83 \pm 12 \S$ & $3.5 \pm 0.5$ & $4.0 \pm 0$ \\
\hline
\end{tabular}

* Rats were not fasted. Diquat dose was $19.5 \mu \mathrm{mol} / \mathrm{kg}$. All values are means \pm SD for four rats in the corn oil group and three rats in the cod liver oil group.

$\$$ Basal ethane production rates have been subtracted.

$\S$ Significantly different by unpaired $t$ test, $P<0.05$.

Mannheim Biochemicals). Malonaldehyde was measured in $0.5 \mathrm{ml}$ of serum by a modification of the method of Ernster and Nordenbrand (15). The thiobarbituric acid-trichloroacetic acid mixture was modified by the addition of $0.5 \% \mathrm{vol} / \mathrm{vol}$ of $2 \%$ butylated hydroxytoluene in ethanol to prevent lipid peroxidation during color development. Malonaldehyde bis(dimethyl acetal) purchased from Aldrich Chemical Co., Inc., Milwaukee, Wis., was used for the standards. Spectral scanning of samples derived from sera of diquat-treated seleniumdeficient rats showed that the increase in absorbance at $535 \mathrm{~nm}$ was the result of development of a peak at that wavelength that is characteristic of malonaldehyde. The 535-nm absorbance in samples derived from sera of rats that did not receive diquat was not associated with the presence of a distinct peak; thus we are uncertain whether the values reported for these rats in Fig. 1 represent malonaldehyde. Glutathione peroxidase was measured with $0.25 \mathrm{mM} \mathrm{H}_{2} \mathrm{O}_{2}$ as substrate by the coupled method previously described (16). The final reaction mixture contained the enzyme source, $1 \mathrm{mM} \mathrm{GSH}$, $5 \mathrm{IU} / \mathrm{ml}$ GSSG reductase, $0.2 \mathrm{mM} \mathrm{NADPH}, 0.25 \mathrm{mM} \mathrm{H}_{2} \mathrm{O}_{2}$, $1 \mathrm{mM}$ EDTA, $1 \mathrm{mM} \mathrm{NaN}$, and $50 \mathrm{mM}$ potassium phosphate buffer $\mathrm{pH}$ 7.0. After a 5 -min preincubation at ambient temperature, the reaction was started by addition of $\mathrm{H}_{2} \mathrm{O}_{2}$, and the decrease in $\mathbf{A}_{340}$ was followed for 2-3 min. Nonenzymatic reaction rates with water replacing the enzyme source were subtracted from all reaction rates. Superoxide dismutase was assayed by the method of McCord and Fridovich (17). Inhibition of the reduction of cytochrome $c$ in the presence of xanthine and xanthine oxidase from $\Delta \mathrm{A}_{5,5} / \mathrm{min}=0.025$, in the absence of tissue fraction, to $\Delta \mathrm{A}_{5,50 \mathrm{O}} / \mathrm{min}=0.0125$, in the presence of tissue fraction, represents $1 \mathrm{U}$ of activity. The amount of tissue fraction added was adjusted to obtain $1 \mathrm{U}$ of activity in the reaction mixture, and the superoxide dismutase activity was calculated from the amount required. Statistical analyses were done with the unpaired $t$ test and Duncan's multiple range test (18).

GSH (yeast type III), NADPH, and paraquat were purchased from Sigma Chemical Co., St. Louis, Mo. $\mathrm{H}_{2} \mathrm{O}_{2}$ was from J. T. Baker Chemical Co., Phillipsburg, N. J. Diquat as the monohydrate (analytical grade) was a generous gift of Mr. Ian Wyatt of Imperial Chemical Industries LTD., Millbank, London, England.

Ethane production measurements. Our method for measurement of ethane production has been described in detail (19). After treatment, rats were placed into individual chambers that contained soda lime to absorb expired $\mathrm{CO}_{2}$ and Drierite (W. A. Hammond Drierite Co., Xenia, Ohio) to absorb expired $\mathrm{H}_{2} \mathrm{O}$. The atmosphere in the chamber was room air and as $\mathrm{O}_{2}$ was consumed more entered the chamber through a tube from a respirometer filled with $100 \% \mathrm{O}_{2}$. The rats were usually kept in the chambers $6 \mathrm{~h}$ and samples of the chamber atmosphere were assayed periodically for ethane that accumulated throughout the experiment. $1 \mathrm{ml}$ of chamber atmosphere was injected into a Hewlett-Packard model 5830A gas chromatograph (Hewlett-Packard Co., Palo Alto, Calif.) with a flame ionization detector. A Porapak-Q 80/100 mesh column was used (Hewlett-Packard). An ethane standard curve was run daily. Using the initial and final ethane concentrations, the volume of the chamber atmosphere, the rat weight, and the time of the experiment, ethane production rate per $100 \mathrm{~g}$ body wt was calculated. With each experiment, appropriate control rats not receiving the toxins were studied and their ethane production rates were subtracted from those

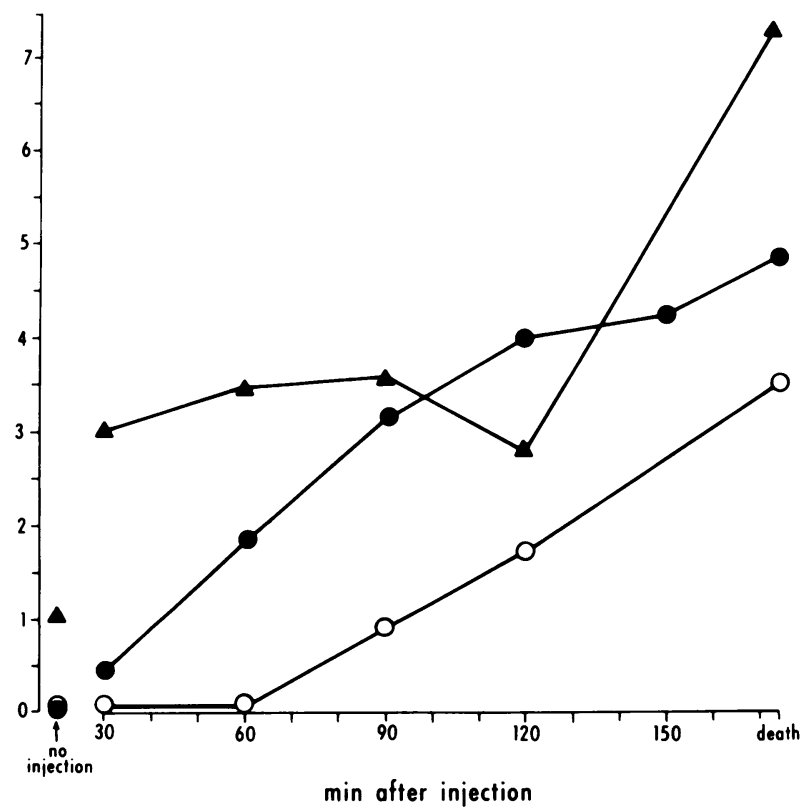

FIGURE 1 Indices of lipid peroxidation and liver necrosis in selenium-deficient rats at various times after they received $19.5 \mu \mathrm{mol} \mathrm{diquat} / \mathrm{kg}$ i. p. Each point is the average of values from two rats. See Methods for details. $\Delta$, serum malonaldehyde $(\mathrm{nmol} / \mathrm{ml}) ; 0$, SGPT $\left(\mathrm{mU} / \mathrm{ml} \times 10^{-3}\right)$; duction (nmol/100 g). 
of the corresponding group given the toxins. Thus, the data presented are ethane production rates due to the toxin.

Histopathology. Except for rats that died before $24 \mathrm{~h}$, samples were collected $24 \mathrm{~h}$ after treatment. About $0.5 \mathrm{~g}$ of tissue was taken from the median and left lobes of the liver and from the left kidney and fixed in $10 \%$ formalin. Hematoxylin and eosin stains were made of two sections of each sample taken from different levels of the tissue block. One of us (Dr. Burk) graded all sections for necrosis without knowledge of their origin. Liver sections were graded as follows: 0-no necrosis; 1-definite necrosis present but necrotic foci numbered fewer than one-half the number of central veins; 2-more foci of necrosis but little confluence of necrosis; 3-extensive confluence of necrosis but large areas of viable tissue remaining; $4-$ massive necrosis with only a few viable hepatocytes remaining. In the animals that died within $3 \mathrm{~h}$, grading was difficult and was based largely on the nuclear changes of chromatin clumping and karyorrhexis. Kidney necrosis was scored as follows: 0-no necrosis; 1 -scattered individual tubular cell necrosis; 2 -necrosis of scttered whole tubules; 3 -necrosis of up to half the tubules; $4-$ necrosis of over half the tubules. Each liver had four sections scored and each kidney two. The values were averaged for each organ to give a necrosis score for the rat.

\section{RESULTS}

The effects of vitamin E deficiency and of selenium deficiency on paraquat- and diquat-induced ethane production and liver and kidney necrosis were determined (Table I). We chose a paraquat dose near the $\mathrm{LD}_{50}(1)$ and used the same dose of diquat on a molar basis. The dose of paraquat given the selenium-deficient rats was reduced because they died within a few hours when given $78 \mu \mathrm{mol} / \mathrm{kg}$.

Each compound caused an increase in ethane production in all groups; diquat caused a greater increase than did paraquat. Diquat-induced ethane production by vitamin E-deficient rats was three times the increase observed in controls. In selenium-deficient rats it was 28 times the control group increase despite the fact that the selenium-deficient rats received only onefourth the dose of diquat given the controls.

Only two groups of rats had evidence of liver and kidney necrosis. There was mild liver and kidney necrosis in vitamin E-deficient rats given diquat, and all of them died within $24 \mathrm{~h}$ of receiving the agent. The selenium-deficient rats given diquat died within 2 $\mathrm{h}$ of receiving diquat, with evidence of severe liver and kidney necrosis. Because of this remarkably rapid injury to the liver and kidney, associated with very high ethane production rates and early death, we investigated further the effect of diquat in selenium deficiency.

The studies shown in Table I were done with animals fed cod liver oil in their diet. Cod liver oil is enriched in omega-3 polyunsaturated fatty acids (linolenic acid family), which yield ethane on peroxidative decomposition (11). An experiment was carried out to compare rats fed the cod liver oil diet with rats fed the corn oil diet (Table II). Selenium-deficient rats from these two diet groups were given diquat. Rats fed the corn oil diet produced one-third as much ethane as those fed the cod liver oil diet, presumably because their tissues contained less omega-3 polyunsaturated fatty acid $(20,21)$. However, evidence of liver and kidney necrosis was unaffected by the diet. Survival time was slightly shorter in the cod liver oil group than in the corn oil group. All subsequent experiments were carried out with rats fed the corn oil diet.

In the experiment shown in Table I, some of the diquat-treated, selenium-deficient rats convulsed shortly before dying, and blood glucose values were very low (not shown). The hypoglycemia was probably the result of the combination of fasting and liver injury. In all subsequent experiments, fed rats were used and hypoglycemia was eliminated (Table II).

The rapid onset of lipid peroxidation and liver injury in selenium-deficient rats given diquat is shown in Fig. 1. Ethane production began within $30 \mathrm{~min}$ and continued until death. Malonaldehyde, a product of lipid peroxidation, was detected in serum in increased amounts $30 \mathrm{~min}$ after diquat administration, and reached a high concentration at death. SGPT was markedly elevated 90 min after diquat administration. Thus, there was evidence of lipid peroxidation by 30 min with evidence of liver damage about an hour later. At death, the blood would not clot. The serum was straw-colored, indicating that little or no intravascular hemolysis occurred.

Because lipid peroxidation and liver necrosis were so striking in selenium-deficient rats given diquat, the experiments shown in Table III were performed to determine whether high doses of diquat or paraquat would have the same effects in control rats. In each case the high dose of toxin killed the control rats within a few hours but caused only a small amount of ethane production and no significant liver necrosis. These findings indicate that paraquat and diquat cause much less lipid peroxidation in control rats than they do in selenium-deficient rats. An additional finding was that diquat was more efficient on a molar basis than paraquat in causing liver necrosis and ethane production in selenium-deficient rats.

Current concepts of the protective effect of selenium against lipid peroxidation center on its role as an essential constituent of glutathione peroxidase (22). This enzyme catalyzes the breakdown of hydrogen peroxide and polyunsaturated fatty acid hydroperoxides, both of which promote lipid peroxidation. Glutathione peroxidase reappears only slowly in tissues of selenium-deficient animals given an injection of selenium (23). Therefore, we injected a physiological dose of the element into selenium-deficient rats and measured its effect on glutathione peroxidase activity $10 \mathrm{~h}$ later (Table IV) and on the effect of diquat injection 
TABLE III

Effects of Lethal Doses of Paraquat and Diquat on Ethane Production and Liver Necrosis in Selenium-deficient and Control Rats*

\begin{tabular}{|c|c|c|c|c|c|}
\hline Agent & Diet group & Dose & $\begin{array}{l}\text { Ethane } \\
\text { produced/100 } \mathrm{g} / \mathrm{ht}\end{array}$ & SGPT & Survival time \\
\hline & & $\mu m o l / k g$ & pmol & $\mathrm{mU} / \mathrm{ml}$ & $\min$ \\
\hline \multirow[t]{3}{*}{ Paraquat } & $\begin{array}{l}\text { Selenium } \\
\text { deficient }\end{array}$ & 78 & $470 \pm 93$ & $212 \pm 87$ & $297 \pm 74$ \\
\hline & Control & 78 & $18 \pm 13$ & $32 \pm 26$ & $-\S$ \\
\hline & Control & 390 & $92 \pm 5$ & $45 \pm 34$ & $106 \pm 30$ \\
\hline \multirow[t]{2}{*}{ Diquat } & $\begin{array}{l}\text { Selenium } \\
\text { deficient }\end{array}$ & 19.5 & $1,940 \pm 420$ & $3,490 \pm 1,940$ & $150 \pm 37$ \\
\hline & Control & 230 & $56 \pm 50$ & $41 \pm 5$ & $80 \pm 12$ \\
\hline
\end{tabular}

\footnotetext{
* Rats were not fasted. Values are mean \pm SD of four values except for the paraquat-treated selenium-deficient group where $n=5$.

\$ Ethane was collected for $6 \mathrm{~h}$ or until death. Basal ethane production rates have been subtracted. They were: control $(n=4) 33 \pm 6$, selenium deficient $(n=3) 67 \pm 5$.

$\$$ All rats survived $24 \mathrm{~h}$.
}

6 and $10 \mathrm{~h}$ later (Table $\mathrm{V}$ ). The selenium injection resulted in insignificant increases in glutatione peroxidase activity in liver, kidney, lung, and plasma at $10 \mathrm{~h}$. In contrast, selenium had a marked protective effect against lipid peroxidation and mortality when given 6 or $10 \mathrm{~h}$ before diquat (Table V). Because there was virtually no increase in glutathione peroxidase activity $10 \mathrm{~h}$ after selenium injection, this result strongly suggests that the protective effect of selenium against diquat toxicity is not due to glutathione peroxidase.

Superoxide dismutase activity was measured in erythrocytes and in $105,000 \mathrm{~g}$ supernates from liver and kidney of selenium-deficient and control rats. There was no difference between groups $(n=4$ in each group, data not shown).
Figs. 2 and 3 demonstrate the severity of the histological liver and kidney injury seen in selenium-deficient rats at death $2-3 \mathrm{~h}$ after diquat injection. A fine vesiculation of hepatocyte cytoplasm and apparent loss of cell boundaries are present. In addition, globules of cytoplasm are seen in the sinusoids and flowing into the central vein (Fig. 2). The kidney exhibits welldeveloped tubular necrosis even though the lesion is $<3$-h old (Fig. 3).

\section{DISCUSSION}

The massive liver necrosis that follows diquat administration to a selenium-deficient rat occurs very quickly. For comparison, administration of carbon tetrachloride

TABLE IV

Effect of Rapid Selenium Repletion on Glutathione Peroxidase Activity

\begin{tabular}{llcccc}
\hline & & \multicolumn{4}{c}{ Glutathione peroxidase** } \\
\cline { 3 - 5 } Diet group & Selenium & \multicolumn{3}{c}{ Homogenates } \\
\cline { 3 - 5 } & injectiont & Liver & Kidney & Lung & Plasma \\
\hline \multirow{2}{*}{$\begin{array}{c}\text { Selenium } \\
\text { deficient }\end{array}$} & No & $9 \pm 2$ & $6 \pm 2$ & $5 \pm 1$ & nmol NADPH/min/ml \\
Control & Yes & $10 \pm 2$ & $9 \pm 1$ & $7 \pm 2$ & $7 \pm 3$ \\
& No & $139 \pm 17$ & $86 \pm 6$ & $67 \pm 18$ & $13 \pm 1$ \\
\hline
\end{tabular}

* Values are means \pm SD of four fed rats. All values from control group were significantly different from the other two groups $(P<0.05)$, but the selenium-deficient injected and noninjected groups were not significantly different from each other by Duncan's multiple range test.

$\$$ One group of selenium-deficient rats received $50 \mu \mathrm{g}$ of selenium as $\mathrm{Na}_{2} \mathrm{SeO}_{3}$ dissolved in $1 \mathrm{ml}$ of $0.14 \mathrm{M} \mathrm{NaCl}$ i.p. $10 \mathrm{~h}$ before sacrifice. 
TABLE V

Effect of Rapid Selenium Repletion on Diquat-induced Ethane Production and Survival Time*

\begin{tabular}{ccc}
\hline $\begin{array}{c}\text { Hours between selenium } \\
\text { and diquat injection }\end{array}$ & $\begin{array}{c}\text { Ethane } \\
\text { produced/100 } \mathrm{g} / \mathrm{h} \uparrow\end{array}$ & $\begin{array}{c}\text { Survival } \\
\text { time } \$\end{array}$ \\
\hline & pmol & $\min$ \\
No selenium & $2,490 \pm 1,020$ & $90 \pm 21$ \\
6 & $760 \pm 588$ & $615 \pm 531^{\prime \prime}$ \\
10 & $232 \pm 288$ & $923 \pm 523 \rrbracket$
\end{tabular}

* Fed selenium-deficient rats were given $50 \mu \mathrm{g}$ of selenium as $\mathrm{Na}_{2} \mathrm{SeO}_{3}$ in $1 \mathrm{ml}$ of $0.14 \mathrm{M} \mathrm{NaCl}$ i.p. and later received 19.5 $\mu \mathrm{mol}$ diquat/kg i.p. Values are means $\pm \mathrm{SD}$ of four rats per group.

\$ Basal ethane production has been subtracted. Ethane was collected for $6 \mathrm{~h}$ from diquat injection or until death if it occurred sooner. The no-selenium group was significantly different from the 6- and 10-h groups $(P<0.05)$, but the 6 - and 10-h groups were not significantly different from each other by Duncan's multiple range test.

$\S$ The no-selenium group was significantly different from the 10-h group $(P<0.05)$, but other pairings were not significantly different by Duncan's multiple range test.

"One rat survived $24 \mathrm{~h}$.

I Two rats survived $24 \mathrm{~h}$.

or of acetaminophen to rats leads to large rises of liver enzymes in serum only after $12 \mathrm{~h}(24,25)$; such a rise occurred by $90 \mathrm{~min}$ after diquat (Fig. 1). At death, which usually occurred $2-3 \mathrm{~h}$ after diquat administration, kidney tubular necrosis was also present. Other tissues, including lung, brain, heart, skeletal muscle, and erythrocytes, were examined for histological evidence of injury; none was found (not shown). Serum creatine phosphokinase activity did not rise signifi-

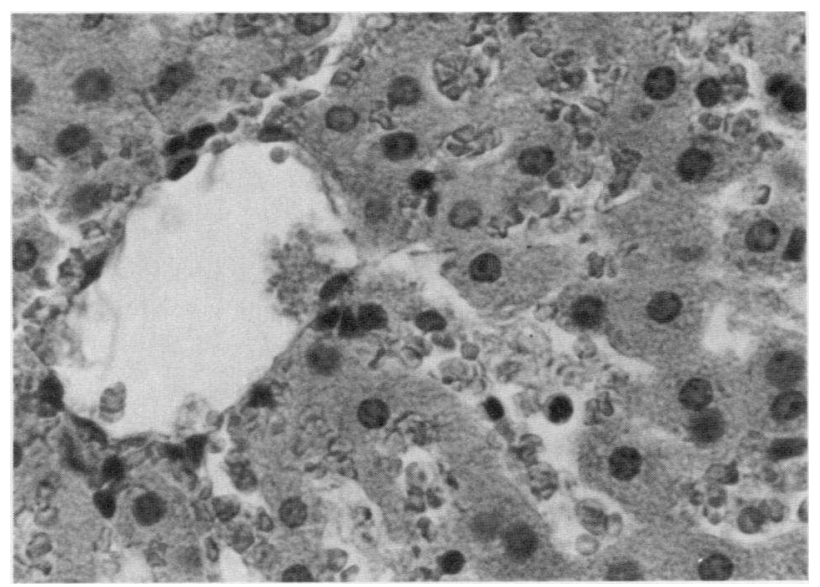

Figure 2 Centrilobular region of the liver of a seleniumdeficient rat given $19.5 \mu \mathrm{mol}$ diquat $/ \mathrm{kg}$. The liver was removed at death $150 \mathrm{~min}$ after diquat injection. The cytoplasm of the hepatocytes is finely vesiculated and clumps of cytoplasm are seen in the sinusoids and entering the central vein. $\mathrm{H} \& \mathrm{E}, \times 400$.

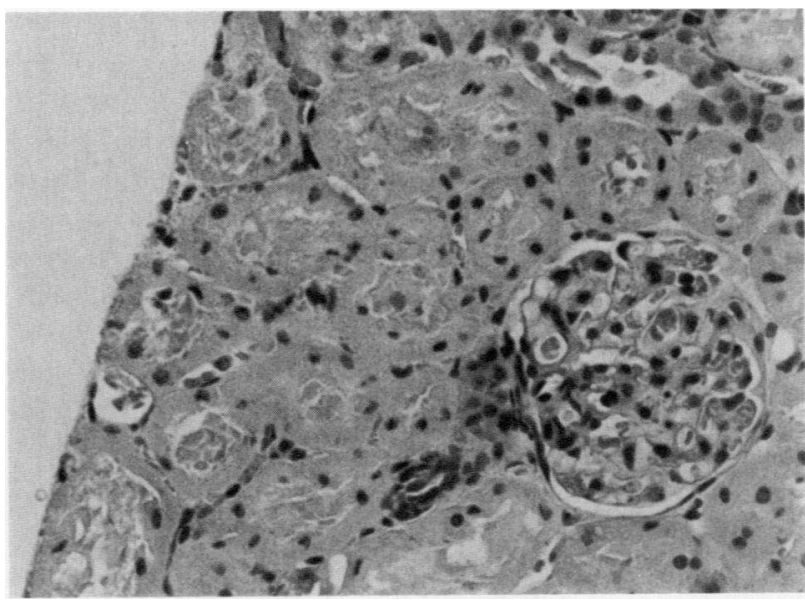

FIGURE 3 Kidney cortex from a selenium-deficient rat given $19.5 \mu \mathrm{mol}$ diquat $/ \mathrm{kg}$. The kidney was removed at death 150 min after diquat injection. Necrosis of almost all tubules is evident. $\mathrm{H} \& \mathrm{E}, \times 200$.

cantly (not shown), indicating that little or no muscle necrosis occurred. The most direct interpretation of these results is that diquat caused very rapid necrosis of the liver and the kidney tubular cells in seleniumdeficient rats with their contents entering the blood stream and resulting in death.

Our findings suggest that lipid peroxidation is the biochemical process responsible for diquat hepatotoxicity in selenium-deficient rats. Lipid peroxidation, as measured by ethane production and by appearance of malonaldehyde in serum, was detected before liver injury became evident (Fig. 1), implying a cause-effect relationship. Moreover, little lipid peroxidation and no liver necrosis was detected in diquat-treated control rats (Table III). Finally, high ethane production is not a necessary result of liver necrosis as demonstrated by the low ethane production rates that accompany liver necrosis as the result of acetaminophen and thioacetamide (19).

The coincidence of lipid peroxidation and liver necrosis has been demonstrated under other circumstances. Combined selenium and vitamin E deficiency, induced in growing rats or pigs. causes massive liver necrosis (26). Rats developing this syndrome, known as dietary liver necrosis, exhale large amounts of ethane, suggesting that the liver necrosis is the result of lipid peroxidation (27). Selenium deficiency alone, however, causes no abnormalities of liver histology. Carbon tetrachloride also causes lipid peroxidation and liver necrosis (28), but some of its metabolites bind covalently in the liver cell, and it is not clear presently what the relative roles of lipid peroxidation and covalent binding are in the liver necrosis due to it. Covalent binding is not known to occur with paraquat and diquat (29). 
Lipid peroxidation might be expected to exert two types of toxicity: local and systemic. Local toxicity would be the result of the direct destructive effect of lipid peroxidation on polyunsaturated fatty acid components of membranes. Because our methods, which depend upon measurement of products of lipid peroxidation at sites remote from their formation, do not allow us to specify the location of the lipid peroxidation, we cannot be certain of the location of such direct toxic effects. It seems most likely to us that lipid peroxidation takes place in the liver cells and in the kidney tubular cells because this study demonstrates rapid necrosis of those cells. However, other investigators have demonstrated that, during the occurrence of lipid peroxidation, substances are produced that can diffuse away from their site of formation and still cause injury (30). Such substances may be related to the malonaldehyde found in the serum of diquat-treated selenium-deficient rats (Fig. 1). Thus, these rats may suffer injury from such substances in tissues where lipid peroxidation is not occurring.

The high ethane production rates noted in diquattreated selenium-deficient rats indicate that lipid peroxidation of a great magnitude occurs under these conditions. The ethane produced during lipid peroxidation is a breakdown product of the linolenic acid family of polyunsaturated fatty acids (11); thus, ethane production should serve as a semiquantitative index of the rate of lipid peroxidation in animals with similar fatty acid compositions (11). From Table I it can be calculated that diquat treatment caused a 139-fold increase in the ethane production rate by seleniumdeficient rats. In a study that we reported elsewhere (19), and that was carried out under identical conditions to the one reported in Table I, carbon tetrachloride caused only a 17 -fold increase in the ethane production rate. This suggests that the rate of diquatinduced lipid peroxidation in selenium-deficient rats is eight times that induced by carbon tetrachloride.

Diquat contains an ethylene bridge that represents a potential source of ethane in these experiments. However, for this to be the source of the ethane we observed, the high ethane production rate in seleniumdeficient rats given diquat and the low ethane production rate in controls would require that metabolism of the diquat to release this bridge as ethane take place only in selenium-deficient rats and not in controls. This seems unlikely. Furthermore, we observed a proportional production of pentane (not shown) that is an expected lipid peroxidation product of the linoleic acid family and a rise in serum malonaldehyde that accompanied the high ethane production rate in selenium-deficient rats (Fig. 1). These findings constitute independent evidence that lipid peroxidation was occurring. Thus, although we cannot completely rule out the possibility of a contribution of the ethylene bridge of diquat to ethane production, it seems unlikely; in any case, there is other evidence of the occurrence of lipid peroxidation.

Selenium deficiency in the rat clearly leads to increased toxicity of diquat and paraquat with ethane production and severe injury of the liver. It is widely considered that the toxicities of these compounds are mediated through their ability to repeatedly accept electrons from cellular enzyme systems and to donate the electrons to $\mathrm{O}_{2}$. Thus, it may be that the seleniumdeficient rat is highly susceptible to lipid peroxidation as the result of $\mathrm{O}_{2}^{-}$. We have been unable to identify the biochemical function of selenium responsible for protection against diquat. Selenium deficiency has no effect on superoxide dismutase activity, and the results in Tables IV and V indicate that the selenoenzyme glutathione peroxidase is not responsible for the protection. Thus, it seems likely that selenium has another biochemical function that is protective against lipid peroxidation as the result of diquat and paraquat.

It is not yet clear whether selenium deficiency occurs in human beings, but it does occur frequently in animals living in areas with low soil selenium content (31). The present findings that selenium deficiency markedly increases the toxicity of these widely used herbicides must raise concern about their use, particularly in low-selenium areas. These findings also illustrate the exquisite interrelationship of nutrition and toxicology.

\section{ACKNOWLEDGMENTS}

The authors are grateful to Mrs. Gale S. Vosley and Mrs. Carol A. Chelette for aid in preparing the manuscript.

This work was supported by National Institute of Health grant ES 01992

\section{REFERENCES}

1. Smith, P., and D. Heath. 1976. Paraquat. CRC Crit. Rev. Toxicol. 4: 411-445.

2. Fisher, H. K., J. A. Clements, and R. R. Wright. 1973. Enhancement of oxygen toxicity by the herbicide paraquat. Am. Rev. Respir. Dis. 107: 246-252.

3. Clark, D. G., and E. W. Hurst. 1970. The toxicity of diquat. Br. J. Ind. Med. 27: 51-55.

4. Farrington, J. A., M. Ebert, E. J. Land, and K. Fletcher. 1973. Bipyridylium quaternary salts and related compounds. V. Pulse radiolysis studies of the reaction of paraquat radical with oxygen. Implications for the mode of action of bipyridyl herbicides. Biochim. Biophys. Acta. 314: 372-381.

5. Bus, J. S., S. D. Aust, and J. E. Gibson. 1974. Superoxideand singlet oxygen-catalyzed lipid peroxidation as a possible mechanism for paraquat (methyl viologen) toxicity. Biochem. Biophys. Res. Commun. 58: 749-755.

6. Omaye, S. T., K. A. Reddy, and C. E. Cross. 1978. Enhanced lung toxicity of paraquat in selenium-deficient rats. Toxicol. Appl. Pharmacol. 43: 237-247.

7. Cagen, S. Z., and J. E. Gibson. 1977. Liver damage following paraquat in selenium-deficient and diethyl maleate-pretreated mice. Toxicol. Appl. Pharmacol. 40: 193-200. 
8. Shu, H., R. E. Talcott, S. A. Rice, and E. T. Wei. 1979. Lipid peroxidation and paraquat toxicity. Biochem. Pharmacol. 28: 327-331.

9. Steffen, C., and K. J. Netter. 1979. On the mechanism of paraquat action on microsomal oxygen reduction and its relation to lipid peroxidation. Toxicol. Appl. Pharmacol. 47: 593-602.

10. Riely, C. A., G. Cohen, and M. Lieberman. 1974. Ethane evolution: a new index of lipid peroxidation. Science (Wash. D. C.). 183: 208-210.

11. Dumelin, E. E., and A. L. Tappel. 1977. Hydrocarbon gases produced during in vitro peroxidation of polyunsaturated fatty acids and decomposition of preformed hydroperoxides. Lipids. 12: 894-900.

12. Lindstrom, T. D., and M. W. Anders. 1978. Effect of agents known to alter carbon tetrachloride hepatotoxicity and cytochrome P-450 levels on carbon tetrachloridestimulated lipid peroxidation and ethane expiration in the intact rat. Biochem. Pharmacol. 27: 563-567.

13. Downey, J. E., D. H. Irving, and A. L. Tappel. 1978. Effects of dietary antioxidants on in vivo lipid peroxidation in the rat as measured by pentane production. Lipids. 13: 403-407.

14. Lawrence, R. A., and R. F. Burk. 1978. Species, tissue, and subcellular distribution of non Se-dependent glutathione peroxidase activity. $J$. Nutr. 108: 211-215.

15. Ernster, L., and K. Nordenbrand. 1967. Microsomal lipid peroxidation. Methods Enzymol. 10: 574-580.

16. Lawrence, R. A., and R. F. Burk. 1976. Glutathione peroxidase activity in selenium-deficient rat liver. Biochem. Biophys. Res. Commun. 71: 952-958.

17. McCord, J. M., and I. Fridovich. 1969. Superoxide dismutase: an enzymatic function for erythrocuprein (hemocuprein). J. Biol. Chem. 244: 6049-6055.

18. Steele, R. G. D., and J. H. Torrie. 1960. Principles and Procedures of Statistics. McGraw-Hill Book Co., New York. 73-75, 107-109.

19. Burk, R. F., and J. M. Lane. 1979. Ethane production and liver necrosis in rats after administration of drugs and other chemicals. Toxicol. Appl. Pharmacol. 50: $467-478$.
20. Century, B., L. A. Witting, C. C. Harvey, and M. K. Horwitt. 1963. Interrelationships of dietary lipids upon fatty acid composition of brain mitochondria, erythrocytes and heart tissue in chicks. Am. J. Clin. Nutr. 13: 362-368.

21. Hammer, C. T., and E. D. Wills. 1978. The role of lipid components of the diet in the regulation of the fatty acid composition of the rat liver endoplasmic reticulum and lipid peroxidation. Biochem. J. 174: 585-593.

22. Hoekstra, W. G. 1975. Biochemical function of selenium and its relation to vitamin E. Fed. Proc. 34: 2083-2089.

23. Correia, M. A., and R. F. Burk. 1978. Rapid stimulation of hepatic microsomal heme oxygenase in selenium-deficient rats: an effect of phenobarbital. J. Biol. Chem. 253: 6203-6210.

24. Lutz, R. W., and T. K. Shires. 1978. Polysomal changes in rats treated with lethal doses of carbon tetrachloride. Toxicol. Appl. Pharmacol. 45: 653-663.

25. Buttar, H. S., E. A. Nera, and R. H. Downie. 1976. Serum enzyme activities and hepatic triglyceride levels in acute and subacute acetaminophen-treated rats. Toxicology. 6: 9-20.

26. Schwarz, K., and C. M. Foltz. 1957. Selenium as an integral part of factor 3 against dietary necrotic liver degeneration. J. Am. Chem. Soc. 79: 3292-3293.

27. Hafemań, D. G., and W. G. Hoekstra. 1977. Lipid peroxidation in vivo during vitamin $\mathrm{E}$ and selenium deficiency in the rat as monitored by ethane evolution. J. Nutr. 107: 666-672.

28. Recknagel, R. O., and A. K. Ghoshal. 1966. Lipoperoxidation as a vector in carbon tetrachloride hepatotoxicity. Lab. Invest. 15: 132-146.

29. Ilett, K. F., B. Stripp, R. H. Menard, W. D. Reid, and J. R. Gillette. 1974. Studies on the mechanism of the lung toxicity of paraquat: comparison of tissue distribution and some biochemical parameters in rats and rabbits. Toxicol. Appl. Pharmacol. 28: 216-226.

30. Benedetti, A., A. F. Casini, M. Ferrali, and M. Comporti. 1979. Effects of diffusible products of peroxidation of rat liver microsomal lipids. Biochem. J. 180: 303-312.

31. Burk, R. F. 1978. Selenium in nutrition. World Rev. Nutr. Diet. 30: 88-106. 